\title{
Impact of Green Supply Chain on Supply Chain Performance
}

\author{
GHUFRAN SAED HIJJAWI \\ Business and Finance Faculty \\ The World Islamic Science and Education University (WISE) \\ P.O Box 1101, Postal Code 11947, Amman, Jordan \\ JORDAN \\ https://orcid.org/0000-0002-3875-2289
}

\begin{abstract}
The purpose of this paper is empirically assessment of the impact of the green supply chain on supply chain performance in terms of social, operational, and environmental, for Jordanian chemical industries. In this paper, the proposed model was developed based on literature review and previous exploratory studies related to GSC and different kinds of SC performance. Tested on sample equal 150 managers of Jordanian detergent manufacturing factories and the returned ones that applicable for analysis were 120 questionnaires, which analyzed using AMOS 27. The results were as follows: there is no impact of green purchase, green production, and green distribution on supply chain performance. While there is an impact of green supply and green design on SC performance, taking into consideration the community and region of study
\end{abstract}

Key-words: green supply chain, green supply, green design, green purchasing, green manufacturing, green distribution, supply chain performance, environmental performance, operational performance, social performance.

Received: August 13, 2021. Revised: December 28, 2021. Accepted: January 17, 2022. Published: January $18,2022$.

\section{Introduction}

As supply chains compete instead of organizations with the spread of globalization and increasing demanding customers; evaluating and measuring the supply chain performance can be considered an indicator for the degree of SC sustainable success, but the issue is that there are many measures for performance (social, environmental, and operational). This comprehensive view of performance is great because it deals with all activities in SC, and trends behind these activities. In addition; it can be configured, and adapted to different industries.

On another side, performance excellence needs special practices in supply chain management; like focus on quality management, customer, and supplier. The term "supply chain management" is used widely to include every effort involved in producing and delivering a final product and service [1]

The green supply chain which saw as an environmentally - friendly/ green movement was triggered by the appeared consequences of environmental debilitation, such as; global warming, water, and air pollution, acid rain, desertification, and noise [2] [3]. Accordingly, the concept of GSC appeared in the 1990s [4]. GSC is a managerial strategy, which uses for environmental business mentoring through planning, purchasing, producing, and delivering the product to the end customers. Effective and efficient management of these supply chains point out the capabilities that have [5].

Thus, this research will focus on filling the gap regarding the impact of GSCM practices on supply chain performance (Social, environmental, Operational) In the Jordanian chemical industry sector. This sector is selected because globally, the chemical industry is the third-largest industrial sector, yields a lot of money for shareholders and for governments as tax revenue, and employs more than 10 million people [6]. In addition, according to study of performance, this paper focus that comprehensive view of supply chain performance rather than organizational performance become critical, and focus on all views of performance is urgent rather than just focus on economic performance. 


\section{Literature Review}

\subsection{Green Supply Chain}

Green supply chain became globally mandatory not optional; not only for organizations but also for countries. The main reason for that is high efficiency and ecology. Despite increasing awareness, not all organizations have fully adopted green supply chain management (GSCM) due to a number of factors [7]. The major factors will be the scarcity of knowledge and techniques in their operation needed to implement GSCM practices, as well as a lack of government initiatives, high costs so others are slow on the uptake, upgrading the employees' expertise, and building new customer perception of products [8].

Ambiguities about GSCM still existed because there are no tangible and short-term benefits for organizations, therefore; legitimate and official support from top management becomes essential to convince of credibility and competence of GSC, and to raise the necessity for the introduction of environmental concerns into the managerial field [9]. GSC is a value chain that integrates environmental activities into supply chain practices; like reducing pollution and wastes, reducing consumption of resources and energy used, and finally extend the life of products through recycling or remanufacturing [8]. And according to this, the concept of GSCM is broad since there are differences among the definitions, there are clear and common usage of several common terms [10] such as; 'supply chain environmental management' [11], 'green purchasing and procurement' [12], 'green logistics, and environmental logistics' [13], and 'sustainable supply network management [14].

Management for GSC is not easy because these chains are more complex than traditional ones. In GSC pollution is prevent instead of just focus on pollution control, energy management is in considerations, and products must be recyclable and reusable. From here and according to [15] GSCM is introducing innovative technical processes into materials supplying and selection, delivery of the final product to consumers, and end-of-life product management. GSCM is management toward green productivity with least harmful to the environment [16].

About drivers and forces toward adopting GSCM, there are many, which are: regulations, consumer demands and awareness, limited resources availability, and global warming according to increased pollution.
Consumer demand and increased environmental awareness; make market pressure on organizations and supply chains to pierce environmental attributes and responsibility through their practices. While local and global regulations are other forces for GSCM to be able to enter new markets. On another side; limited resources availability was a great force especially for unrenewable resources and decreasing in them made unbalance in the environment.

Main GSC practices are: green purchasing or consumption, green manufacturing and products' end of life management, green logistics ( distribution, warehousing, and green transportation with usage of biofuels); while [17] see that GSC practices consist of (green procurement, environmental management of manufacturing materials, environmental circulation, marketing, and reverse logistics) and according to [18], it is defined as a combination of the activities that categorizes as (product design, all stages of manufacturing and distribution and all aspects of reverse logistics).

Consequently, the practices for GSC adopted in this paper are green design, green purchasing, green manufacturing, and green distribution (logistics);

\subsubsection{Green Design}

[19] Defined (GSCM) main practices through the product life cycle model and found that eco-design term was used to refer to green design. Moreover, confirm eco-design importance in the GSCM, as it requires extended cooperation among designers, suppliers, and customers to achieve cleaner production. On another side, [20] explained that GD mainly aimed at reducing the negative impact on the environment all over the life cycle of the product, this is achieved through resource-saving, pollution avoidance, waste management, and designing products for reuse and recycling.

\subsubsection{Green Purchasing/ Consumption}

Before defining green purchasing or consumption, it is essential to know in advance, what the meaning of a green product is. In general, there are several attributes to distinguish a green product. For example; it is an ecologically friendly product, not harmful to human or animal health, does not consume excessive amounts of energy during manufacturing, and does not produce unnecessary waste. In addition, a green product uses contents that can be recycled [21]. 
On the other hand, [21] defined green consumption, which is also called Environmentally Preferable Purchasing (EPP); as a kind of responsible consumption, in which consumers consider the environmental impact of buying, using, and discarding of different items, or using various sustainable and green services.

For green purchasing, [22] illustrate from their studies that there are several intentions: some of these are personal factors such as (trust, habit, emotions, personal norms, and values), and others are situational factors like (product, price, availability, social norm /subjective norm and reference groups, eco-labeling and certification). While [23] made their studies on Turkish consumers seen GP behavior related to consumers' demographic attributes. Furthermore [24], added according to his research on youth people's behavior in Pakistan that GP intentions are strongly related to the role and support of the government for environmental purchasing. From other studies like [25] study, which performed an empirical study on Lebanese consumers. They examined four factors that might affect GP behavior, which are perceived seriousness of environmental problems, perceived environmental behavior effectiveness, perceived environmental responsibility, and concern for self-image in environmental protection.

Green purchasing is a complicated practice that must consider not only traditional factors, such as a supplier's cost, lead-time, quality, and flexibility but also environmental responsibility [26]. Furthermore, green purchasing may require extensive suppliers, educated coaching, and mentoring [27], so building certain capabilities in an organization is essential before adopting green purchasing practices.

\subsubsection{Green Manufacturing (GM)}

Being ecologically responsible, through the different phases of the manufacturing process, is the definition of green manufacturing. Applying GM practices has several advantages over traditional manufacturing methods, such as pollution control, energy conservation, and waste reduction [28].

[29] inferred their own definition for GM, which is based on the concept of being alert to environmental impact at all manufacturing stages from input until output. In addition, the main practices that can be applied according to their research are; minimizing raw materials, decreasing cost and energy consumed, and reducing waste and pollution.

[30] Discussed different ways to achieve GM, for example; applying Just-in-time in lean manufacturing and the 5S methodology. Moreover, they confirmed that using renewable resources like water, wind, tidal, and biodiesel in generating energy is essential for energy conversion, which is one of the main practices in GM.

\subsubsection{Green Distribution.}

Green distribution is essential in enhancing the environmental performance of industrial firms; this is achieved through the efficient use of fuel and optimization of the distribution network (route planning). And this is what, [31] discussed according to GD that can be achieved by using greener vehicles in distribution networks, such as electric vehicles, which in turn reduces greenhouse gas emissions and therefore decreases air pollution. According to [32] green distribution includes environmentally friendly packaging and transportation. However, [33] study green distribution main practices, where; eco-labeling, green packaging, green shipping or transportation, and green storage.

\subsection{Supply Chain Performance}

Performance measurement methods were evolved to indicate monitoring and retaining organizational control. SC performance measurement is the process to ensure that $\mathrm{SC}$ aims at strategies that lead to the achievement of its overall goals [34].

The Performance Attributes are characteristics of the supply chain that allow it to be analyzed, and evaluated against other supply chains with competing strategies. Members of the supply chain may have different organizational missions, and goals, so the existence of performance metrics and the exact way for measurement across the chain can help align organizations, promote the redesigning of business goals, and reform processes to meet supply-chain demands [35]. Therefore, the choice of performance measure is one of the most critical challenges facing organizations [36]. Wrong measures give wrong signals for managers and consequently wrong decisions.

Recent studies established that sustainable performance including environmental, economic, and social performance [37], so; in this paper, the focus was on these three kinds of performance. 


\subsubsection{Operational Performance}

Operational performance is the most famous and critical measure of performance especially for stockholders; it refers to the measurable aspects of the outcomes of SCM practices, such as reliability, production cycle time, and inventory turns. [38], [39] define operational performance to be a feasible critical clear option when one intends to inspect the direct effects of organizational activities such as workforce development. Thus, for a supply chain that seeks high-quality products and customer satisfaction, focus on operational performance becomes essential [40].

Typical measures of operational performance can be efficiency, effectiveness, service quality, production quality, sales, and innovation [41]. These operational measures can be obtained through both subjective estimates, and objective measures.

\subsubsection{Environmental Performance}

Research suggests that a firm's environmental strategy has wide ranges expand from being proactive to reactive [42]. One study suggests that the relationship between its corporate social responsibility and environmental performance can be mediated by firm's environmental strategy [43], with the findings indicating that a firm's environmental strategy is an important variable that can influence the effect of GI on its environmental performance.

\subsubsection{Social Performance}

Social performance refers to "improvement of stakeholder welfare, community health and safety, employee's health and safety, and reduction of risk on the public" [35].

\subsection{Green Supply Chain and Supply Chain Performance}

According to the literature review, "impact of GSC with different types of performance" was a wide focus field for many academics, and the results were different.

The first view was implementing green supply chain management practices can be a burden, and just a cost on organization and entails huge upfront investments thus negatively affects financial or operational performance especially in the short term [44], [45]. Others like [46] and [47]. [48] investigated the relations among economic performance, environmental performance, and GSC. The author found that there is a positive relationship between economic performance and environmental performance and that of GSC. While recent findings of different studies of the green supply chain were opposite of past studies, most of the studies motivate and support adopting GSC practices in their industries to improve organizational and SC performance. [49] Illustrate that adoption of GSC practices by manufacturing organizations leads to improved environmental performance and economic performance, which, in turn, positively affect operational performance. [50] found after analysis that GSC with TQM and JIT practices have a great effect on environmental performance.

\section{Study hypotheses and Model}

Based on the above literature the study hypotheses can be formulated as follow:

H0.1: There is no effect of green supply chain at a significance level $(\alpha \leq 0.05)$ on supply chain performance in Jordanian manufacturing factories.

H0.1.1: There is no effect of green supply at a significance level $(\alpha \leq 0.05)$ on supply chain performance in Jordanian manufacturing factories.

H0.1.2: There is no effect of green purchasing at a significance level $(\alpha \leq 0.05)$ on supply chain performance in Jordanian manufacturing factories.

H0.1.3: There is no effect of green (production) manufacturing at a significance level $(\alpha \leq 0.05)$ on supply chain performance in Jordanian manufacturing factories.

H0.1.4: There is no effect of green design at a significance level $(\alpha \leq 0.05)$ on supply chain performance in Jordanian manufacturing factories.

H0.1.5: There is no effect of green distribution at a significance level $(\alpha \leq 0.05)$ on supply chain performance in Jordanian manufacturing factories.

The following theoretical framework, shown in Fig. 1 , may support the hypotheses of the study 


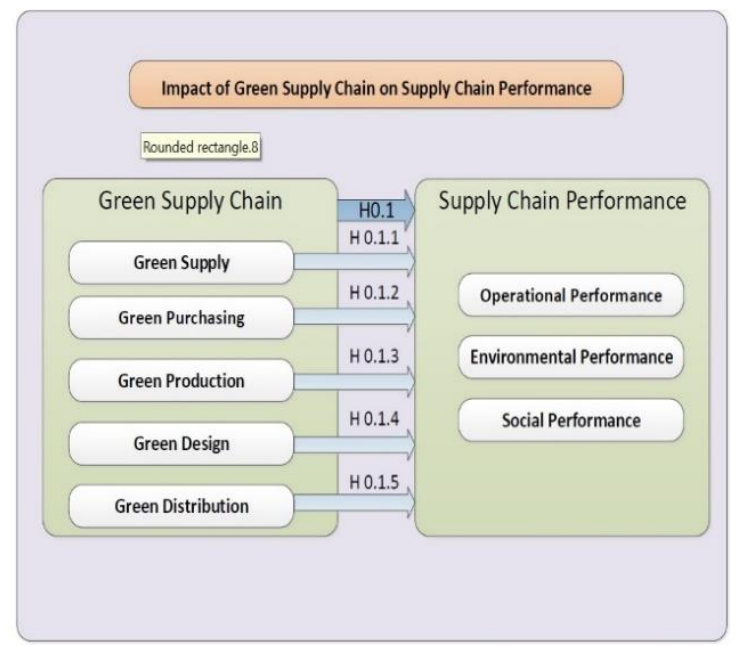

Fig. 1: Research proposed model

\subsection{Methodology}

In this study, data is collected based on both primary and secondary data, therefore; a questionnaire designed based on the proposed model, which developed based on literary reviews that serve as primary data source for research variables.

\subsubsection{Sample of the Study}

A sample of 150 has been randomly taken from the population of chemical detergent manufacturing companies in Jordan. In this study, the unit of analysis was employees at different managerial levels. This manufacturing sector was selected because it is one of the dominant mature industries in Jordan that has huge numbers of Jordanian workers with huge interest especially in Covid-19 period. The questionnaires were distributed to 150 employees with managerial and technical experience, out of which 120 were returned and suitable for statistical analysis. Subjects were asked to assess their perceptions about different constructs. Assessments were based on a five-point Likert scale ranging from "strongly disagree (1) to "strongly agree (5) in order to measure the 39 items.

\subsubsection{Reliability and Validity Test}

In order to test validity, the survey instrument was distributed to a number of professionals and academics to determine whether the survey was comprehensive, understandable, and measured appropriate content. Their feedback was considered before forming the final copy of the questionnaire. Scale reliability was measured using Cronbach's alpha $(\alpha)$ and. All the values of Cronbach's for each of the constructs of (GSC, supply chain performance) ranged from 0.835 to 0.960 , which consequently exceeding the suggested threshold of 0.70 [51]. This, in turn, is an indicator of suitable internal consistency. These findings have been presented in Table. 1.

Table 1. Reliability (Cronbach Alpha $(\alpha)$ )

\begin{tabular}{|l|l|l|l|}
\hline Construct & $\begin{array}{l}\text { Measurement } \\
\text { item }\end{array}$ & $\begin{array}{l}\text { Cronbach } \\
\text { Alpha }\end{array}$ & $\begin{array}{l}\text { Cronbach } \\
\text { Alpha }\end{array}$ \\
\hline \multirow{5}{*}{ GSC } & Green Supply & 0.871 & \multirow{5}{*}{0.953} \\
\cline { 2 - 3 } & Green Purchasing & 0.892 & \\
\cline { 2 - 3 } & Green Production & 0.835 & \\
\cline { 2 - 3 } & Green Design & 0.845 & \\
\cline { 2 - 3 } & $\begin{array}{l}\text { Green } \\
\text { Distribution }\end{array}$ & 0.862 & \\
\hline \multirow{5}{*}{ SCP } & $\begin{array}{l}\text { Operational } \\
\text { Performance }\end{array}$ & 0.901 & \multirow{4}{*}{0.960} \\
\cline { 2 - 3 } & $\begin{array}{l}\text { Environmental } \\
\text { Performance }\end{array}$ & 0.913 & \\
\cline { 2 - 3 } & $\begin{array}{l}\text { Social } \\
\text { Performance }\end{array}$ & 0.917 & \\
\hline
\end{tabular}

\subsubsection{Discriminant Validity Test}

Variable correlation of the constructs used to evaluate the discriminant validity of the overall measurement model. According to [52] discriminant validity is acceptable when the value of the correlation between the constructs lower than its value of AVE. Therefore, none of the correlation coefficients was greater than 1.00 , which indicates that the findings have acceptable discriminant validity.

Table 2. Discriminate Validity

\begin{tabular}{|l|c|r|r|r|r|r|}
\hline & design & supply & prod & purch & distr & SCP \\
\hline design & 1.000 & & & & & \\
\hline supply & .220 & 1.000 & & & & \\
\hline prod & .272 & .129 & 1.000 & & & \\
\hline purch & .267 & .166 & .085 & 1.000 & & \\
\hline distr & .081 & .121 & .058 & .104 & 1.000 & \\
\hline SCP & .530 & .389 & .266 & .293 & .207 & 1.00 \\
\hline
\end{tabular}

\subsubsection{Normality Test}

A normality test is used to check whether the data is normally distributed or skewed either to the right side or to the left side [52]. These values are referred to as Kurtosis variables, which can influence the relationship examination as well, the significance test. The normality test performed in this study used two common measures namely Skewness and Kurtosis with values not exceeds 2 and 7, which are considered sufficient normally 
distributed data [53]. Table. 3 presents the values of both skewness and kurtosis of the studied indicators which indicated that the skewness of the indicators ranged from -0.003to 0.267 while the kurtosis values were between -0.320 and 0.868 . Thus, all of the measurements had skewness and kurtosis values ranked within \pm 2 and \pm 7 , respectively. Therefore, it indicates that the dataset has a normal distribution.

Table 3. Assessment of normality

\begin{tabular}{|c|c|c|c|c|c|c|}
\hline Variable & Min & Max & $\begin{array}{l}\text { Ske } \\
\mathrm{w}\end{array}$ & c.r. & $\begin{array}{l}\text { kurtosi } \\
\text { s }\end{array}$ & c.r. \\
\hline Design & .277 & $\begin{array}{l}7.27 \\
9\end{array}$ & $\begin{array}{l}0.26 \\
7\end{array}$ & $\begin{array}{l}1.19 \\
4\end{array}$ & 0.820 & $\begin{array}{l}1.83 \\
3\end{array}$ \\
\hline Supply & $\begin{array}{l}0.79 \\
4\end{array}$ & $\begin{array}{l}6.56 \\
3\end{array}$ & $\begin{array}{l}0.18 \\
9\end{array}$ & $\begin{array}{l}0.84 \\
7\end{array}$ & -0.320 & $\begin{array}{l}- \\
0.71 \\
5\end{array}$ \\
\hline Purchase & $\begin{array}{l}0.87 \\
0\end{array}$ & $\begin{array}{l}6.41 \\
2\end{array}$ & $\begin{array}{l}0.19 \\
5\end{array}$ & $\begin{array}{l}0.87 \\
1\end{array}$ & -0.165 & $\begin{array}{l}- \\
0.36 \\
8\end{array}$ \\
\hline Production & $\begin{array}{l}0.69 \\
1\end{array}$ & $\begin{array}{l}7.34 \\
7 \\
\end{array}$ & $\begin{array}{l}0.17 \\
9\end{array}$ & 0801 & 0.304 & $\begin{array}{l}0.68 \\
0 \\
\end{array}$ \\
\hline $\begin{array}{l}\text { Distributio } \\
\mathrm{n}\end{array}$ & $\begin{array}{l}- \\
0.75 \\
0\end{array}$ & $\begin{array}{l}6.81 \\
8\end{array}$ & $\begin{array}{l}- \\
0.00 \\
3\end{array}$ & $\begin{array}{l}- \\
0.01 \\
5\end{array}$ & 0.868 & $\begin{array}{l}1.94 \\
2\end{array}$ \\
\hline SCP & $\begin{array}{l}2.00 \\
0\end{array}$ & $\begin{array}{l}5.00 \\
0 \\
\end{array}$ & $\begin{array}{l}0.24 \\
0\end{array}$ & $\begin{array}{l}1.07 \\
4\end{array}$ & 0.411 & $\begin{array}{l}0.91 \\
9\end{array}$ \\
\hline $\begin{array}{l}\text { Multivariat } \\
\mathrm{e}\end{array}$ & & & & & 3.878 & $\begin{array}{l}2.16 \\
8\end{array}$ \\
\hline
\end{tabular}

\subsubsection{Hypotheses Test}

Table 4. Maximum Likelihood Estimates (MLE) and Regression Weights (hypothesis testing):

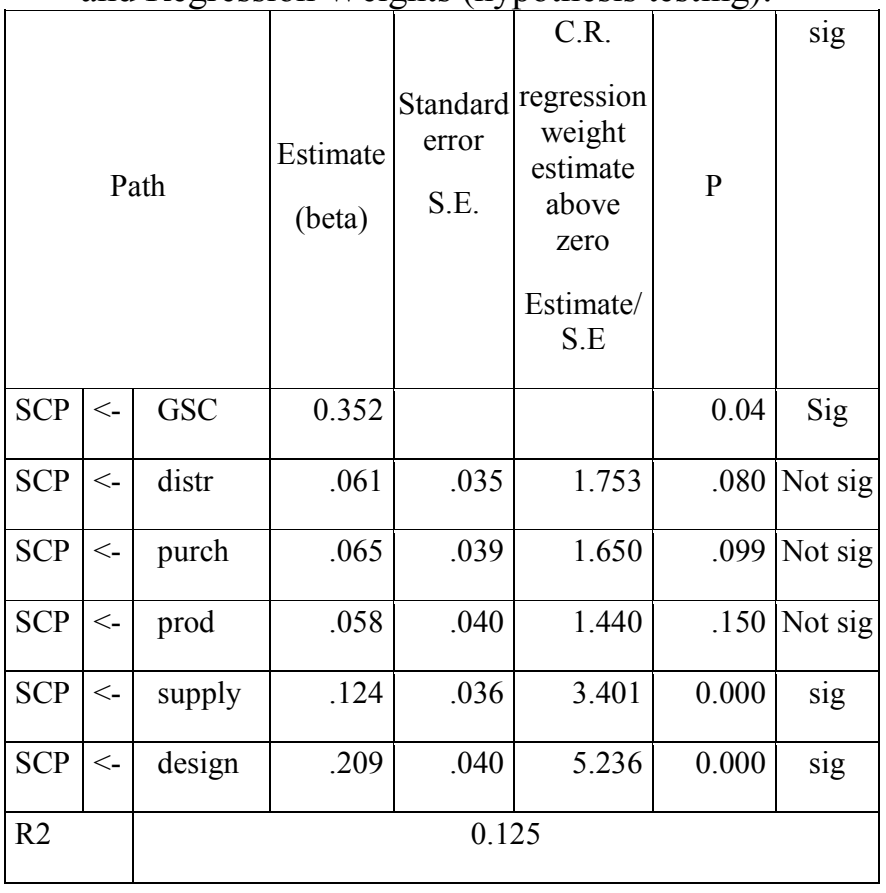

From the previous table, it is obvious that there is no significant effect of green purchase, green production, and green distribution on supply chain performance, where all of these impacts have significance more than 0.05 . However, on another side; green supply and green design have significant effects on supply chain performance with significance less than 0.05 . While, the overall impact of GSC on performance is significant with $(\mathrm{R} 2=0.125)$ which indicates that the relation is medium according to [54]. This relation is medium because GSC needs moderators such as TQM and JIT practices to improve its effect, while JIT practices did not practice in the Jordanian manufacturing sector.

Table 5. Coheen measurement of R2

\begin{tabular}{|l|l|}
\hline effect & Range of R2 \\
\hline weak & Less than 0.13 \\
\hline medium & $0.13-0.26$ \\
\hline strong & Greater than 0.26 \\
\hline
\end{tabular}

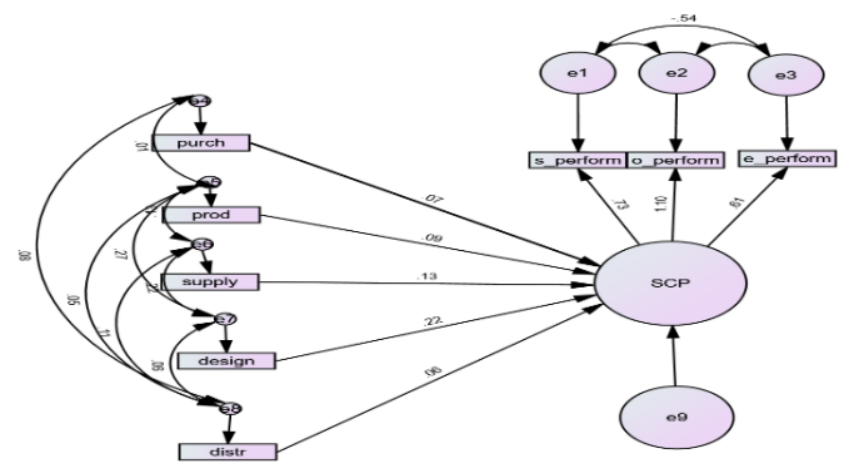

Fig. 2: Hypotheses Test 
Table 6. Model identification and Model Fit Summary in AMOS

\begin{tabular}{|c|c|c|c|c|}
\hline \multicolumn{5}{|c|}{ Model identification } \\
\hline \multicolumn{2}{|c|}{$\begin{array}{l}\text { Number of distinct } \\
\text { sample moments: }\end{array}$} & \multicolumn{3}{|c|}{21} \\
\hline \multicolumn{2}{|c|}{$\begin{array}{l}\text { Number of distinct } \\
\text { parameters to be } \\
\text { estimated: }\end{array}$} & \multicolumn{3}{|c|}{18} \\
\hline \multicolumn{2}{|c|}{$\begin{array}{l}\text { Degrees of freedom } \\
(21-18)\end{array}$} & \multicolumn{3}{|c|}{3} \\
\hline \multicolumn{5}{|c|}{$\begin{array}{l}\text { Model Fit Summary(Mueller \& Hancock, } \\
\text { 2019) }\end{array}$} \\
\hline & \begin{tabular}{|l} 
Chi- \\
square \\
$=$ \\
CMIN
\end{tabular} & DF & \begin{tabular}{|l|}
$\mathrm{P}<$ \\
0.05 \\
\\
Model \\
fit
\end{tabular} & $\begin{array}{l}\text { CMIN/DF } \\
\text { Less than } \\
2\end{array}$ \\
\hline $\begin{array}{l}\text { Default } \\
\text { model }\end{array}$ & 2.231 & 3 & .526 & .744 \\
\hline $\begin{array}{l}\text { Saturated } \\
\text { model }\end{array}$ & .000 & 0 & & \\
\hline \multirow{2}{*}{$\begin{array}{l}\text { Independence } \\
\text { model }\end{array}$} & 90.035 & 15 & .000 & 6.002 \\
\hline & RMR & $\begin{array}{l}\text { GFI }< \\
=0.9\end{array}$ & $\begin{array}{c}\text { AGFI }< \\
=0.9\end{array}$ & PGFI \\
\hline $\begin{array}{l}\text { Default } \\
\text { model }\end{array}$ & .045 & .994 & .958 & .142 \\
\hline $\begin{array}{l}\text { Saturated } \\
\text { model }\end{array}$ & .000 & 1.000 & & \\
\hline \multirow{2}{*}{$\begin{array}{l}\text { Independence } \\
\text { model }\end{array}$} & .192 & .767 & .673 & .548 \\
\hline & $\begin{array}{c}\text { NFI } \\
<= \\
0.90\end{array}$ & & & \\
\hline $\begin{array}{l}\text { Default } \\
\text { model }\end{array}$ & .975 & & & \\
\hline $\begin{array}{l}\text { Saturated } \\
\text { model }\end{array}$ & .975 & & & \\
\hline \multirow[t]{2}{*}{$\begin{array}{l}\text { Independence } \\
\text { model }\end{array}$} & 1.000 & & & \\
\hline & \multicolumn{4}{|c|}{ RMSEA must be less than 0.08} \\
\hline model & \multicolumn{4}{|l|}{.000} \\
\hline \multicolumn{5}{|l|}{ Decision } \\
\hline \multicolumn{5}{|c|}{$\begin{array}{l}\text { Fitness model for non- } \\
\text { significance of chi-square }\end{array}$} \\
\hline
\end{tabular}

The results relating to fit models generally support a good fit and can be observed in Table supporting a good fit, because the ratio of chi-square and degree freedom has a value of 0.744 (CMIN/DF), is less than 2.0 [55]. In addition, the root means a square error of approximation (RMSEA $=0.00$ is below 0.08 . The goodness of fit index (GFI) for this model is an acceptable value because it is more than 0.80 , the minimum limit. The comparative fit index (CFI) was also positioned within the acceptable rates considered for small sample sizes [56]

\section{Discussion and Conclusion}

The research aims to examine if there is any impact of different green supply chain practices (green supply, green purchase, green design, green production, and green distribution) in Jordanian chemical industries, on supply chain performance dimensions.

This sector was specifically selected because the chemical manufacturing industry in any country accounts for a large proportion of environmental impact. Moreover; manufacturing is also responsible for the depletion and consumption of natural resources in any region and, consequently, it produces large harmful wastes to the environment.

In this study; the result was there is a significant impact of GSC on SC performance with significance equal to (0.04), but as an individual effect of substructures of GSC, there is no significant effect of (green purchase, green production, and green distribution) on SC performance, while there is a significant effect of (green supply and green design) on SC performance. These SC practices and SC performance were studied by different researchers in different communities. However, the results were conflicting. For [57] study on manufacturing industries in UEA, gives that there is a positive relationship between different GSCs on different aspects of corporate performance (economic, social, operational, and environmental). While [58] made on manufacturing companies in Ghana. , it gives that there is no positive effect of green warehousing and distribution on economic performance. Moreover, [59] found that GSC in the USA manufacturing sector has a great impact on environmental performance and this impact will be more and more if TQM and JIT practices combined into GSC. Another study for [60] discovered that the adoption of GSCM practices by manufacturing 
organizations leads to positively affect operational performance, which, in turn, enhances organizational performance.

As a result, it is obvious that the maturity degree of governmental regulations regarding eco-friendly industries affects the impact of GSC on performance; because the same practices at different regions give different results. On another side, a particular green supply chain practice should be supported by specific organizational capabilities to achieve the intended performance which means; when choosing a green supply chain, firms should select practices that "fit" with their existing resources and capabilities [61], [62] thus in Jordanian Chemical industries, firms still need to build and construct competitive capabilities and have distinguished and sustainable resources in logistics and supply to have an impact on performance.

The researcher concludes that management support, governmental regulations, and social perception of environmental products are critical to getting the real and strong effect of GSC on performance.

Table 7. Results of hypotheses and its implications

\begin{tabular}{|l|l|l|}
\hline Hypothesis & Result & \multicolumn{1}{|c|}{ Implications } \\
\hline H0.1.2 & $\begin{array}{l}\text { Not } \\
\text { sig }\end{array}$ & $\begin{array}{l}\text { Jordanian chemical industries may } \\
\text { need to successfully adopt green } \\
\text { purchasing; the development of their } \\
\text { supplier appraisal, SCM } \\
\text { skills/knowledge, better external } \\
\text { integration capabilities, and other } \\
\text { resources. }\end{array}$ \\
\hline H0.1.3 & $\begin{array}{l}\text { Not } \\
\text { sig }\end{array}$ & $\begin{array}{l}\text { Jordanian chemical industries may } \\
\text { need SCM skills/knowledge, foster } \\
\text { internal integration, and supply chain } \\
\text { flexibility capabilities to successfully } \\
\text { adopt their green manufacturing } \\
\text { strategies }\end{array}$ \\
\hline H0.1.5 & $\begin{array}{l}\text { Not } \\
\text { sig }\end{array}$ & $\begin{array}{l}\text { Jordanian chemical industries may mand } \\
\text { need advanced IT systems to assure } \\
\text { internal and external integration, more } \\
\text { capabilities in logistics. }\end{array}$ \\
\hline
\end{tabular}

\section{Limitations of Study}

The limitations of this study are several; which need to be discussed in future studies. First, it only considered GSC practices without any mediator or moderator variables (company size, strategy, company age, industry sector) between it and supply chain performance. Second, the findings of the study suffer from limited generalization. This is because the study was only limited to Jordanian chemical industries and this was because the purpose of the study was how to improve manufacturing practices in Jordan, in particular; does going green and consider implementing green supply chain management practices led to improve different kinds of performance. Third, it measures $\mathrm{SC}$ performance as a whole; further studies could assess specific kinds of performance (operational, economic, social, and environmental).

\section{References:}

[1] Morana, Ivakovic; Darko, Babic, \& Marinko, Jurcevice (2010). Decision Support Systems in Supply Chain Management. International Conference Transport,Maritime and logistics science. 27-28 may, portoroz slovenija

[2] Chen, T.B. and Chai, L.T. (2010), Attitude towards the environment and green products: consumers' perspective, Management Science and Engineering, 4(2), 27-39

[3] Gong R.F., Xue, J., Zhao, L.J., Zolotova, O., JI, X.Q., XU, Y. (2019). A Bibliometric Analysis of Green Supply Chain Management Based on the Web of Science (WOS) Platform. Sustainability, 11, 3459.

[4] Badi, S., Murtagh, N. (2009) Green supply chain management in construction: A systematic literature review and future research agenda. Journal of Cleaner Production, 223, 312-322.

[5] Lannelongue, Gustavo (2015). Time compression diseconomies in environmental management: The effect of assimilation on environmental performance. Journal of Environmental Management.147: 203-212.

[6] Bhusnure, O.G., Dongare, R.B., Gholve, S.B. \& Giram, P.S. (2018). Chemical hazards and safety management in pharmaceutical industry. Journal of Pharmacy Research | 12(3), 357369.

[7] Wang, W., Zhang, Y., Zhang, W., Gao, G., Zhang, H. (2021) Incentive mechanisms in a green supply chain under demand uncertainty, Journal of Cleaner Production, https://doi. org/10.1016/j.jclepro.2020.123636

[8] Jaggernath, Runala, Khan, Zaffar (2015). Green supply chain managemen, World Journal of Entrepreneurship, Management and Sustainable Development, 11(1), 37-47

[9] Jabbour, Charbel José, Stefanelli, Chiappetta Nelson Oliveira (2021). FIFTEEN YEARS OF GREEN SUPPLY CHAIN RESEARCH, UFSM, Santa Maria,14(1), 202-212

[10] Sarkis, J. Zhu, Q., Lai, K. (2011). An organizational theoretic review of Green supply 
chain management literature. International Journal of Production Economics, (130), 1-15

[11] Sharfman, Mark, Teresa M. Shaft, and Robert P. Anex Jr.(2009). The Road to Cooperative Supply-Chain Environmental Management: Trust and Uncertainty Among Pro-Active Firms, Wiley InterScience, 18,1-13

[12] Min, H. and Galle, W.P. (2001), "Green purchasing practices of US firms",

International Journal of Production and Operations Management, Vol. 21 No. 9, pp. 1222-1238.

[13] Murphy.P.R, Poist.R.F. (2000). Green Logestic Strategies: an Analysis of usage Patterns. Transp.J, 5-16.

[14] Young,A., Keilkeiwicz-Young, A.(2001). Sustainable Supply Network Managament, Corp. Enversion.Strategy 8 (3), 260-268

[15] Industry Canada (2013), Logistics and Supply Chain Management Green Supply Chain Management: Retail Chains and Consumer Product Goods - A Canadian Perspective, Industry Canada.

[16] Wang, H.-F. and Gupta, S.M. (2011). Green Supply Chain Management Product Life Cycle Approach, McGraw-Hill Professional, New York, NY

[17] Hervani, A.A., Helms, M.M. and Sarkis, J. (2005), "Performance measurement for green supply chain management", Benchmarking: An International Journal, 12(4), 330-353.

[18] Sarkis, J. (2003), "A strategic decision framework for green supply chain management", Journal of Cleaner Production, 11(4), 397-409.

[19] Zhu, Q., Sarkis, J., \& Lai, K. H. (2019). Choosing the right approach to green your supply chains. Modern Supply Chain Research and Applications.

[20] Islam, S., Karia, N., Fauzi, F. B. A., \& Soliman, M. (2017). A review on green supply chain aspects and practices. Management \& Marketing. Challenges for the Knowledge Society, 12 (1), 12-36.

[21] Moisander, J. (2007). Motivational complexity of green consumerism. International journal of consumer studies, 31(4), 404-409.

[22] Joshi, Y., \& Rahman, Z. (2015). Factors affecting green purchase behaviour and future research directions. International Strategic management review, 3(1-2), 128-143

[23] Seyrek, I. H., \& Gul, M. (2017). Factors Affecting Green Purchasing Behavior: A Study of Turkish Consumers. International
Journal of Academic Research in Business and Social Sciences, 7(1), 306-319.

[24] Soomro, R. B., Mirani, I. A., Ali, M. S., \& Marvi, S. (2020). Exploring the green purchasing behavior of young generation in Pakistan: opportunities for green entrepreneurship. Asia Pacific Journal of Innovation and Entrepreneurship.

[25] Dagher, G. K., \& Itani, O. (2014). Factor influencing green purchasing behaviour: Empirical evidence from the Lebanese consumers. Journal of Consumer Behavior, 13(3), 188-195.

[26] Lee, S.-Y. and Klassen, R.D. (2008), "Drivers and enablers that foster environmental management capabilities in small-and medium-sized suppliers in supply chains", Production and Operations Management, 17(6), 573-586.

[27] Holt, D. (2004), Managing the interface between suppliers and organizations for environmental responsibility - an exploration of current practices in the UK, Corporate Social Responsibility and Environmental Management, 11(2), 71-84.

[28] Belekar, A. M. (2017). Green manufacturing. International Research Journal of Engineering and Technology, 4(7), 26672671.

[29] Setyaningsih, I., Ciptono, W. S., Indarti, N., \& Kemal, N. I. V. (2019). What is Green Manufacturing? A Quantitative Literature Review. In E3S Web of Conferences (Vol. 120, p. 01001). EDP Sciences.

[30] Bisoyi, B., Das, D., Subbarao, P. S., \& Das, B. (2019, November). An Evaluation on Green Manufacturing: It's Technique, Significance and Rationality. In IOP Conference Series: Materials Science and Engineering (Vol. 653, No. 1, p. 012032). IOP Publishing.

[31] Trivellas, P., Malindretos, G., \& Reklitis, P. (2020). Implications of Green Logistics Management on Sustainable Business and Supply Chain Performance: Evidence from a Survey in the Greek Agri-Food Sector. Sustainability, 12(24), 10515

[32] Sahar, D. P., Afifudin, M. T., \& Indah, A. B. R. (2020). Review of green supply chain management in manufacturing: A case study. In IOP Conference Series: Earth and Environmental Science, 575(1), 012239. IOP Publishing.

[33] Kirunga, F., \& Kihara, A. (2018). Influence of Green Distribution Practices Environmental Performance of Chemical Manufacturing 
Firms In Kenya. Journal of International Business, Innovation and Strategic Management, 2 (3), 197-214

[34] Azim, MD. , Ahmad, Helaluddin, and Khan, A.T.M. Shipper (2015). Operational Performance and Profitability: An Empirical Study on the Bangladeshi Ceramic Companies. International Journal of Entrepreneurship and Development Studies (IJEDS) 3(1), 63-73

[35] Chan, F.T.S. \& Qi, H.J. (2003). An innovative performance measurement method for supply chain management. Supply Chain Management. An International Journal, 8, 209-223

[36] Ittner, C. D., \& Larcker, D. F. (1998). Innovations in Performance Measurement: Trends and Research Implications. Journal of Management Accounting Research , 10 (2), 205-238.

[37] Yusliza, Yong, Jing Yi, Tanveer, M. Imran, Ramayah, Juhari Noor Faezah, \& Zikri Muhammad (2020). A structural model of the impact of green intellectual capital on sustainable performance. Journal of Cleaner Production, 249

[38] Voss, C. A., Åhlström, P., \& Blackmon, K. (1997). Benchmarking and operational performance: some empirical results. International Journal of Operations \& Production Management, 17(10),1046 - 1058

[39] Turkulainen, V. \& Ketokivi, M. (2013). The contingent value of organizational integration. Journal of Organization Design, 2(2), 31-43.

[40] Truong, H.Q., Sameiro, M., Fernandes, A.C., Sampaio, P., Duong, B.T., Duong, H.H., \& Vilhenac, E. (2017). Supply chain management practices and firms' operational performance. International Journal of Quality \& Reliability Management, 34(2), 176-193.

[41] Tomic, I., Tesic, Z., Kuzmanovic, B. \& Tomic M. (2018). An empirical study of employee loyalty, service quality, cost reduction and company performance. Economic ResearchEkonomska Istraživanja, 31(1), 827-847

[42] Fousteris,A.E, Didaskalou, E.A, Tsogas, M.M.H, Geargakellos,D.A,(2018). The environmental strategy of businesses as an option under recession in Greece.Sustainability 10(12),4399.

[43] Rehman, Shafique Ur, Kraus b, Sascha , Shah c, Syed Asim, Khanin d, Dmitry, \&Mahto, Raj V.(2021). Analyzing the relationship between green innovation and environmental performance in large manufacturing firms. Technological Forecasting \& Social Change, 163

[44] Zhu, Q., Sarkis, J. and Lai, K. (2007), "Green supply chain management: pressures, practices and performance within the Chinese automobile industry", Journal of Cleaner Production, 15 (11-12), 1041-1052.

[45] Rothenberg, S., Pil, F.K. and Maxwell, J. (2001), "Lean green and the quest for superior environmental performance", Production and Operations Management, 10 (3), 228-43.

[46] Friedman, M. (1962), Capitalism and Freedom, University of Chicago Press, Chicago, IL.

[47] Jaffe, A.B., Peterson, S., Portney, P. and Stavins, R. (1995), "Environmental regulation and the competitiveness of US manufacturing: what does the evidence tell us?", Journal of Economic Literature, 33( 1),132-63.

[48] Al-Tuwaijri, S., Christensen, T. and Hughes, K. (2004), "The relations among environmental disclosures environmental performance, and economic performance: a simultaneous equations approach", Accounting Organizations and Society, 29 ( 5), $447-471$

[49] Green Jr, Kenneth W., Zelbst, Pamela J., Meacham, Jeramy and Bhadauria, Vikram S. (2012). Green supply chain management practices: impact on performance, 17 (3), 290-305

[50] Green, Kenneth W., Inman, R. Anthony, Sower, Victor E. , \& Zelbst, Pamela J.(2019). Impact of JIT, TQ and green supply chain practices on environmental sustainability, 30 (1), 26-4

[51] Hair Jr, J. F., Sarstedt, M., Hopkins, L. and Kuppelwieser, V. G. (2014). Partial least squares structural equation modeling (PLSSEM): an emerging tool in business research. European Business Review, 26 (2), 106-121

[52] Ong, M. H. A., \& Puteh, F. (2017). Quantitative data analysis: Choosing between SPSS, PLS, and AMOS in social science research. International Interdisciplinary Journal of Scientific Research, 3(1), 14-25.

[53] Peng, B., Robert, K. Y., DeHoff, K. L., \& Amos, C. I. (2007). Normalizing a large number of quantitative traits using empirical normal quantile transformation. Paper presented at the BMC proceedings.

[54] Cohen, S. and Roussel, J. (2005), Strategic Supply Chain Management: The Five Disciplines for Top Performance, McGraw- 
Hill, New York, NY. de Bakker, F., Fisscher, O. and Brack, A. (2002), "Organizing product-oriented environmental management from a firm's perspective", Journal of Cleaner Production, 10(5), 455-64

[55] Mueller, R. O., \& Hancock, G. R. (2019). Structural equation modeling: Routledge/Taylor \& Francis Group.

[56] Hair, J. F., Money, A. H., Samouel, P., \& Page, M. (2007). Research methods for business. Education+ Training.

[57] Younis, Hassan, \& Sundarakani, Balan (2019). The impact of firm size, firm age and environmental management certification on the relationship between green supply chain practices and corporate performance. Benchmarking: An International Journal. 27(1), 319-346

[58] Mensah, Yaw Agyabeng, Ahenkorah, Esther, Afum, Dacosta, Ebenezer Essel \& Dacosta, Essel (2020). Green warehousing, logistics optimization, social values, and ethics and economic performance: the role of supply chain sustainability. The International Journal of Logistics Management, 31 (3), 549-574

[59] Green, Kenneth W. , Inman, R. Anthony, Sower, Victor E. , and Zelbst, Pamela J. (2019). Impact of JIT, TQM and green supply chain practices on environmental sustainability. Journal of Manufacturing Technology Management ,30(1),26-47

[60] Green Jr, Kenneth W. , Zelbst, Pamela J., Meacham, Jeramy and Bhadauria, Vikram S.(2012). Green supply chain management practices: impact on performance. Supply Chain Management: An International Journal, 17(3), 290-305

[61] Christmann, P. (2000), Effects of 'best practices' of environmental management on cost advantage: the role of complementary assets, The Academy of Management Journal,43(4) , 663-680

[62] Mahoney, J.T. (1995). The management of resources and the resource of management, Journal of Business Research, 33(2), 91-101.

\section{Creative Commons Attribution License 4.0} (Attribution 4.0 International, CC BY 4.0)

This article is published under the terms of the Creative Commons Attribution License 4.0 https://creativecommons.org/licenses/by/4.0/deed.e n US 